\title{
Progressive Taxation versus Progressive Targeted Transfers in the Design of a Sustainable Value Added Tax System
}

\author{
Zhila Abshari $^{1}$, Glenn P. Jenkins ${ }^{1,2, * \mathbb{D}}$, Chun-Yan Kuo ${ }^{2}$ and Mostafa Shahee ${ }^{3}$ \\ 1 Department of Economics, Eastern Mediterranean University, Famagusta 99628, Turkey; zhila_a@yahoo.com \\ 2 Department of Economics, Queen's University, Kingston, ON K7L 3N6, Canada; kuoc@econ.queensu.ca \\ 3 Department of Policy Studies, Queen's University, Kingston, ON K7L 3N6, Canada; msshahee@gmail.com \\ * Correspondence: jenkins@econ.queensu.ca
}

check for

updates

Citation: Abshari, Z.; Jenkins, G.P.; Kuo, C.-Y.; Shahee, M. Progressive Taxation versus Progressive Targeted Transfers in the Design of a Sustainable Value Added Tax System. Sustainability 2021, 13, 11165. https://doi.org/10.3390/ su132011165

Academic Editors: Mihaela Onofrei and Marc A. Rosen

Received: 10 August 2021

Accepted: 5 October 2021

Published: 10 October 2021

Publisher's Note: MDPI stays neutral with regard to jurisdictional claims in published maps and institutional affiliations.

Copyright: (c) 2021 by the authors. Licensee MDPI, Basel, Switzerland. This article is an open access article distributed under the terms and conditions of the Creative Commons Attribution (CC BY) license (https:// creativecommons.org/licenses/by/ $4.0 /)$.

\begin{abstract}
Value added tax (VAT) has proven to be the most stable and revenue productive of all components of the tax system. However, for such a tax system to be policy sustainable over time, taxpayers must consider it fair, and it must be viewed by the National Treasury to be productive in terms of raising substantial revenue and administratively feasible by the VAT-implementing agency. The VAT system in Belize has been a highly productive component of the revenue system, and it was designed to be progressive, but in arriving at this position, over $40 \%$ of the personnel of VAT tax administration are engaged in processing tax refunds to promote progressivity and to fight against the fraud that such a refund system incubates. This is an unsustainable position for any tax system to remain intact over time. This paper evaluates the attempt by the government of Belize to introduce progressivity into their single-rate VAT through zero rating and exemption from taxation of many goods and services that are major expenditure items of poor households. The distributional impacts are measured by a tax reform that eliminates all zero ratings except for exports and a few exemptions. By eliminating zero-rated items and significantly reducing the number of exempt items, the impact of the reform adds a regressive element, although overall, the VAT system remains progressive. However, $75 \%$ of the revenues raised by this reform would be paid by the top $40 \%$ of the income distribution. The increased revenues could finance an expansion of an existing transfer scheme that exclusively targets poor households. In addition, reforms would eliminate at least $40 \%$ of the personnel costs of administering the current VAT system.
\end{abstract}

Keywords: distributional impacts; progressive; regressive; GST; VAT; targeted expenditure transfer; Belize

\section{Introduction}

Over the past two decades, substantial efforts have been made to reform tax systems in many countries to promote efficiency and effectiveness. Many countries still need to make further reforms to modernize their tax systems. Some currently have a relatively low ratio of tax revenue to gross domestic product while requiring more revenue for infrastructure development or social sector expenditures. As VAT constitutes a large proportion of tax revenues in many countries, a broad tax base for VAT is highly desirable [1-4].

As the theory suggests, a more efficient taxation system can be achieved by applying an equal tax rate to all goods and services [5]. However, imposing a broad-based uniform standard VAT may have limited appeal because it will likely increase the price of many essential goods for the poor [6-9]. As [10] pointed out, while the burden of General Sales Tax (GST) in the short run depends on the relative price elasticities of demand and supply of the goods and services purchased, the tax is likely to be entirely shifted forward to final consumers in the long run. This observation is supported empirically [11].

VAT has been a highly successful tax system in most countries. However, there have been situations in which the VAT system became so unpopular that it was not sustainable. In some cases, countries have had to revert to a single-stage sales tax that was previously 
replaced by VAT. For example, after VAT was implemented in Belize, it had to be withdrawn in 1999. It was not reintroduced for seven years due to political concerns regarding its possible regressivity. Its reintroduction was motivated by the need to significantly raise revenue. After implementing VAT in April 2015, Malaysia decided to replace it with a single-stage retail tax in September 2018. The reason for this decision was due to public protests over its administration and incidence. However, the previous level of revenues raised by VAT has not been sustained by single-stage sales and services tax.

Ghana is a good illustration of the need to have a transparent, well-structured VAT system that is easy to administer if the system is to remain sustainable. VAT was first implemented in 1995 to replace a sales tax system applied to goods and services. It almost immediately collapsed due to the lack of preparation of the administration and education of the taxpayers on how a VAT system needs to function. The VAT system was reintroduced in 1998 after more thorough preparation. However, from 1998 to 2014, a series of ad hoc amendments were made to the law and regulations in much the same way as that recently experienced by Belize. As a consequence of a growing complicated and cumbersome administrative system, a new VAT legislative and regulatory package was introduced in 2014 as a comprehensive reform of the VAT taxation system in Ghana.

While Belize has potentially one of the most efficient tax systems in the world, the general sales tax revenue-raising potential has been eroded by numerous exemptions, as well as the zero rating of a wide range of products and services. The general sales tax now has effective differential rates across sectors, and it is also uncertain whether these special provisions are, in fact, sustainable and benefit the intended groups. While the VAT system of taxation is generally considered a sustainable tax system, a VAT system with several exemptions and a complicated set of zero ratings of domestic sales can easily become unsustainable.

The traditional hypothesis of the incidence of VAT is based on the idea that because poorer households spend a larger proportion of their income on consumption, they are also likely to pay a higher average tax rate than higher income households. This may sound logical; however, it is based on the assumption that rich and poor households purchase similar goods, and the tax base is always at the retail price level and fully taxed. No differentiations are made between sales made to poor or wealthy households. However, this is not the case in reality, especially in developing economies [12].

The reason for the progressivity of VAT is due to the usual way by which tax is administered and the possible limits on the level of taxpayer compliance. In many countries, there is a sales threshold level below which small retailers are legally exempt from collecting tax on their sales while, at the same time, not receiving a refund for the taxes they pay on their taxable inputs. This exemption is given because the administration costs of VAT collection from these informal retailers are much higher than any additional taxes collected. At the same time, these are the establishments where lower income households do most of their shopping.

In most developing countries, higher income households tend to purchase goods and services at retail outlets, such as supermarkets, which almost fully comply with tax rules. Hence, the share of consumption subject to VAT for higher income households tends to be greater than for the poor. Due to the fact that the poor are more closely connected to informal markets, there is a natural tendency for the incidence of VAT to be progressive [13,14].

In tax policy formulation, broadening the tax base is often opposed by those who believe that the poor will be negatively affected and will bear relatively more of the burden of a broad-based VAT. Some items are categorized as necessities to prevent widening income inequality and become subject to zero rating or exemption from VAT. Such policies may be counterproductive when the absolute amount of expenditures made by wealthy households on such necessities is much greater than that of poor households. In Keen's review of related studies, it concluded that the benefits of these implicit subsidies were, indeed, much greater for higher income than for lower income households [15]. 
A similar study for New Zealand showed that a multi-rate VAT might enhance the progressivity of the tax system but would benefit wealthier households more than poorer households [16]. On the other hand, how well a targeted transfer scheme performs depends on how efficiently it can deliver benefits to households in lower quintiles. A well-targeted scheme needs to disproportionally allocate a higher share of the total additional revenue from tax reform to lower income households [17].

During the period from 2005 to 2013, the Fiscal Economics Division of the Interamerican Development Bank undertook a large number of studies across Latin America on various aspects of VAT. The main theme of this work was to develop solutions to simultaneously design a VAT base that yielded progressive consumption tax as well as a broad tax base with a uniform tax rate so that it would have a minimum level of compliance, an administrative uniform rate, and relief for the poorest taxpayers. These studies considered the alternative designs of the VAT system, their relative administrative complexities, the income distribution impacts of these alternative designs, and mitigating measures that might be undertaken. Their studies covered most countries in Central and South America. Their main conclusions were that VAT should be designed as broadly and uniformly as administratively possible. At the same time, a substantial amount of additional tax revenues should be spent in a fashion targeting the specific needs of the poor groups in these countries [18-20].

As Belize is an English-speaking country in South America, the InterAmerican Development Bank sponsored a special tax reform study in 2005 to review its tax systems. This study by [21] strongly recommended that the government implement a broad-based, single-rate value added tax system once again. As the government at the time had a fiscal crisis, this recommendation was accepted, and VAT was introduced and named GST. This is a credit-invoice type of VAT system. Belize is classified by the World Bank as an upper-middle-income country, with a per capita income in 2017 of USD 4906 [22]. However, it also has a high incidence of poverty. Approximately $41.3 \%$ of the population lives below the poverty line, with $16 \%$ facing extreme poverty [23].

The tax structure in Belize broadly comprises direct and indirect taxes and, in the last decade, has consistently yielded revenues in the range of $21.0 \%$ to $25.0 \%$ of GDP. Around $70.0 \%$ of the total tax revenues was raised through indirect taxes, and $30.0 \%$ came from direct taxes. At present, the central government revenue-raising taxes are Personal Income Tax (PAYE), Business Tax, GST, and Import Duty. Of the total tax revenues collected for 2000-2017, PAYE and GST account for 9.2\% and 31.3\%, respectively [24].

A relatively small proportion of individuals in Belize are subject to personal income tax. In Belize, individual income tax is levied on a PAYE basis on the incomes of employed persons whose income is accrued in or derived from Belize. The basic exemption, which is now BZD 26,000 or USD 13,000, means that hardly anyone in the bottom three quintiles of income distribution will be subject to personal income tax. In such a situation, it is neither cost effective nor economically efficient to try to broaden the scope and administration of individual income tax so that a refundable income tax credit could be implemented to give relief to low-income individuals from GST. Hence, income tax is not a useful institutional mechanism for delivering tax relief from GST.

As a developing country with a substantial informal sector, Belize has collected about $8.0 \%$ of gross national product each year since 2014 through its GST system with a single statutory tax rate of $12.5 \%$ [25]. This analysis is conducted for Belize using data from the Household Expenditure Survey (HES) conducted by the Belize Bureau of Statistics in 2008-2009 (the latest available survey) and the GST policies in 2016. The information available for Belize and the effectiveness of its tax administration provides an almost ideal basis for the evaluation of the income distribution impacts of pro-poor indirect tax policies. Belize is an ideal country for conducting a comparative analysis of the budgetary efficiency of indirect tax expenditures versus direct expenditures for poverty alleviation. The conclusions of this study have wide applicability in other developing countries. The quality of information and access to the senior policymakers and tax administrators have 
provided the authors with first-hand information on the actual policy motivations and actions taken over time to increase the degree of progressivity in the GST system.

This study has three objectives. First, we evaluate the incidence of the VAT across the distribution of households ranked by their level of total expenditures. An analysis is then carried out to assess the impact of the removal of tax measures designed to make the tax incidence more progressive. Second, we estimate the total value of the tax expenditure created by these tax preferences and allocate these tax expenditures to each of the quintiles of households.

Lastly, we evaluate the degree to which the additional revenue might finance an expansion of an already existing targeted poverty alleviation program. Much of the previous work in this area has employed potential income transfer schemes such as refundable tax credits [26] or cash transfers [9]. The challenges of administering such offsetting expenditure programs have often been overlooked. In Belize, there is a pro-poor assistance program with a track record already in place, although the program has been constrained owing to budgetary considerations. In this analysis, we evaluate the potential uses of additional revenues from the reduction in the zero rating and exemption of pro-poor goods and services to expand a targeted pantry program.

This paper is organized as follows: Sections 2 and 3 describe the existing and proposed tax systems, respectively, to highlight the reforms. Section 4 contains the data and methodology that describes how the effective tax rates and the overall incidence of the existing tax system are estimated. In Sections 5 and 6, estimates are made of the current and the proposed tax system's overall incidence and distributive impacts. Finally, Section 7 describes how the additional revenue generated by the proposed tax system might be used to mitigate the burden of tax changes and alleviate the poverty of very poor households. Section 8 discusses the option of targeted cash transfers, and, finally, Section 9 contains the conclusion and policy recommendations.

\section{Existing Tax System}

Effective as of 1 July 2006, the "sales tax" in Belize was replaced by a credit-invoice type of VAT named GST. All businesses with an annual turnover of more than BZD 75,000 (USD 37,500) are obliged to register for tax. The standard rate of GST was increased to $12.5 \%$ on 1 April 2010. Taxable supplies are taxed either at this standard rate or at $0 \%$. While exported items are zero rated, imports are subject to the same rate as domestically produced goods and services. The GST on imports is paid simultaneously as the customs duty, and the GST is calculated on the duty-inclusive value of goods plus any other taxes other than the GST.

Over time, several amendments have been made to render the GST more progressive by reducing or eliminating the taxation of several items. Zero-rated items include many food items for human consumption; water supply (other than bottled water); some medicines and medical supplies for human use; some items and supplies for use in education; and some supplies related to agriculture, livestock, birds, fish, crustaceans, and mollusks. Accordingly, it has been observed that the most controversial policy issue in designing VAT is the tax treatment of food, and Belize is certainly no exception to this observation [27]. By 2016, a total of 177 commodities and services were zero rated. In addition, a total of 144 items were made exempt from GST. Any GST paid on purchases used to produce zero-rated supplies may be reclaimed, resulting in a tax-free supply.

Under the current tax system in Belize, taxpayers submit a monthly general sales tax (GST) return, regardless of whether it is a debit, credit, or zero return. Taxpayers with more than three months' tax credit are candidates for refunds. The Audit Supervisor recommends those candidates to the GST Commissioner, who in turn selects some for audit while approving others. The major problem that tax auditors in Belize have faced is the identification of false claims for input taxes paid on inputs used to produce zero-rated items versus those used to produce exempt items or those used in personal consumption. The partial zero-rated method is utilized to determine the input tax that can be reclaimable 
by registered taxpayers for partially taxable and partially zero-rated items. However, it is time consuming to determine the legitimate tax credits for inputs used in zero-rated items and those used to produce exempt items or those that are consumed personally and should not be refunded. As small and medium family businesses dominate the Belize economy, many inaccurate claims were submitted. In the past, penalties were modest for filing a false claim. Hence, the number of claims increased. This is quite different from the common problems in the EU with the carousel fraud operations that are dominated by organized criminals operating across borders. The current situation in Belize has resulted in a considerable number of refund claims by those claiming to be producing zero-rated items. In 2018 , over $40 \%$ of the staff assigned to the administration of GST were working on the processing of refunds. Even with this commitment of resources, the backlog of claims for refunds accumulated to the extent that in 2016, they amounted to about 50\% of the annual net VAT revenues. This situation makes it difficult for any VAT system to remain viable.

In the past, policymakers in Belize were reluctant to raise the threshold for VAT registration in order to reduce the number of small tax filers. It was thought that a higher threshold would prevent many small firms that produce zero-rated items for domestic consumption, such as agricultural goods, from claiming such refunds. If the reforms proposed in this article were implemented, the volume of refunds for input tax credits for domestic sales would be eliminated. This would enable an increase in the threshold that would provide tax administration with further relief.

\section{Proposed Tax System}

While the single tax rate of $12.5 \%$ remains unchanged, the proposed reforms can be summarized in three stages. They initially involved the elimination of as many zerorated items as administratively possible, except for items exported. Following the reform, 100 of the 177 zero-rated items would be classified as tax exempt. These items include unprocessed foods, and the remaining zero-rated items that constituted processed foods would become fully taxable. Finally, the number of exempt items would be reduced from 144 to 92 , with the remaining 52 becoming fully taxable.

The effective tax rates of exempt items are a function of their input shares. For exempt items, the inputs are taxed, but no refund is given for taxes paid on these inputs. To obtain effective tax rates of exempt items, it is essential to estimate the input share of each exempt item separately. Multiplication of the tax rate by the input share of each item would yield an effective tax rate for that item [28]. Given that GST paid on the purchase of the inputs of zero-rated items is refundable, their effective tax rates would remain equal to zero.

From a tax policy perspective, the proposed reform would significantly reduce the administrative and compliance costs of GST. The reforms could also substantially increase the stream of tax revenues that the Government of Belize could redistribute to help alleviate the poverty of targeted households and provide the funding necessary to finance the expansion of infrastructure required to sustain economic growth.

\section{Data and Methodology}

The estimation of the incidence of GST is the study of the economic burden of this tax as different economic groups in society pay it. To analyze the distributional impact of such a tax, the average tax payment as a proportion of an appropriate base for each household group needs to be calculated [10]. Individuals tend to make their highest incomes during their middle years of life, earning less in the early stage of their careers and retirement. Hence, the use of annual income to measure the progressivity of the VAT becomes problematic. As has been pointed out, income is also volatile and subject to temporary shocks [29]. As a result, the position of a typical household relative to its life cycle is neglected if its income is measured for a specific period.

An ideal measure of the distributional burden of tax would be the ratio of the present value of taxes paid over an individual's lifetime to the present value of their lifetime 
earnings. Although this may be conceptually sound, it is impossible to estimate in practice, as such data are not available [30].

Due to these constraints, total expenditures made during a period have been used as a proxy for household welfare. Total expenditures are less volatile than current income and tend to be a better proxy for permanent income. They are also less likely to be underreported than current income. Because consumption tends to be more evenly distributed than income in most countries, studies that use consumption as a welfare measure tend to find that consumption-based taxes are more progressive than studies that use current income [29].

The database used to analyze the incidence of the current GST system and the proposed reformed system is a nationally representative HES. The latest available HES was conducted during the period of 2008-2009 by the Belize Bureau of Statistics. The survey consists of a sample of 2287 households across six different districts, and the HES collects household expenditure information on 1500 commodity groups.

In this paper, we took the economic unit as defined by the household expenditure survey. This definition of the household unit does not consider the household composition in terms of the number and age of the household members. For some purposes, in assessing the income distribution impacts of tax policy changes, a more refined measure of the economic unit expresses the expenditures and incomes of surveyed households into standardized equivalent consumption units. Such an approach has been taken in a study of the income distribution impacts of tax policy changes in the Czech Republic [31]. In this study, different family members are weighted to express households in terms of one-member household equivalents. In this paper, the same definition of the household unit is used as that employed by the HES. This definition is convenient as it is also compatible with the non-standardized household unit used by the pantry expenditure program, whose income distribution impact is examined later.

In the HES, households were asked what establishments they bought various items from. We know that lower income households tend to make relatively more purchases in informal markets and smaller stores where GST is unlikely to be collected because either the turnover is below the threshold for registration or it is too administratively expensive to collect tax. Most small retailers and informal vendors pay GST when they purchase goods for sale or pay for inputs such as electricity and fuel. Hence, there is some GST content built into the cost of their sales.

In the survey, households were given a choice of seven different kinds of establishments from which they could purchase an item. If they purchased the item from either a supermarket or a hardware store, it is expected that they would pay the full statutory rate of GST. If they purchased the item from a vendor, shop, variety store, food stall, or other informal establishments, the full statutory rate of GST would not be reflected in the sales price.

Following the methodology outlined in [13], tax coefficients were created according to the type of establishment where the item was purchased. Their value measures the proportion of the final sales price that is subject to VAT. The rationale behind this approach is that vendors charge tax on sales with the consumption-type VAT and receive credits for taxes paid on the purchases of business inputs used in the production of taxable sales. It is, however, essential to recognize that even if a commodity is subject to VAT, the tax may not be levied or collected on some of its final sales. Examples include most vendors and sales made in neighborhood shops. This is legal when the annual value of sales from a business is lower than the small business threshold. The same result is likely to arise for purchases from stores that do not issue invoices.

It is often assumed that the consumption of the same goods and services is taxed at the same effective rate of VAT for households at different income levels. However, the estimated tax coefficients show that this is usually not the case when we evaluate the distribution of the tax burden. As shown in Table 1, a tax coefficient of 1 means that the retail price is subject to the full rate of GST. However, a coefficient of less than 1 reflects the 
ratio value of the taxed inputs in each sector to the final retail price. If no GST is collected on the final sale, the seller will not be allowed to claim a credit for the GST paid on their input purchases. In such situations, the retail price will have substantial tax content but not the full rate of the GST. These coefficients were estimated by reducing the effective tax rates for the loss of retail margins from the tax base for the sector using the social accounting matrix of Belize. The assumption is made that that all of the inputs purchased by the sector are subject to GST. However, for the food sold in food stalls, a small survey of such establishments was undertaken, and the value of taxed inputs as a proportion of final sales price was estimated to be about $30 \%$.

Table 1. Tax coefficient matrix by commodity and establishment type.

\begin{tabular}{cccccccc}
\hline \multirow{2}{*}{ Commodity Type } & \multicolumn{7}{c}{ Place of Purchase } \\
\cline { 2 - 7 } & Supermarket & Hardware Store & Street Vendor & Shop & Variety Store & Food Stall & Other \\
\hline Food & 1 & 1 & 0.70 & 0.70 & 0.70 & 0.30 \\
Clothing and cosmetics & 1 & 1 & 0.85 & 0.85 & 0.85 & 0.85 \\
Housing utilities & 1 & 1 & 0.70 & 0.70 & 0.70 & 0.85 \\
Furniture and house & 1 & 1 & 0.75 & 0.75 & 0.75 & 0.75 \\
equipment & 1 & 1 & 0.70 & 0.70 & 0.70 & 0.70 \\
Health & 1 & 1 & 0.85 & 0.85 & 0.85 & 0.85 \\
Transportation & 1 & 1 & 0.65 & 0.65 & 0.65 & 0.65 \\
Entertainment & 1 & 1 & 0.50 & 0.50 & 0.50 & 0.75 \\
Education & 1 & 1 & 0.30 & 0.30 & 0.30 & 0.65 \\
Hotels and restaurants & 1 & 1 & 0.70 & 0.70 & 0.70 & 0.50 \\
Other goods and services & 1 & & & 0.30 \\
\hline
\end{tabular}

The first step is to rank households in ascending levels of their total expenditure to evaluate tax incidence. Then, based on the item's tax treatment, commodity-specific effective GST tax rates are calculated. It must first be recognized that the expenditures reported in the HES are inclusive of GST. Hence, the standard GST rate of $12.5 \%$ on the net-of-tax base becomes a standard rate of $11.1 \%$ on the value of expenditures on an item inclusive of the VAT paid at the time of its purchase. The effective rates for goods and services that were not legally exempted or zero rated are estimated by taking the standard tax rate of $11.1 \%$ and multiplying it by the tax coefficients reported in Table 1 that correspond to the type of establishment from which the household purchased the item.

For this purpose, the effective tax rate for every commodity is estimated both before and after the reform, according to the type of establishment from which the item was purchased. These effective tax rates are then applied to the expenditures made on goods and services by category. The incidence of GST by quintile and major commodity groups is estimated before and after the reform. To reflect the behavioral response to the changes in retail prices caused by the changes in tax rates, the consumers' utility function is assumed to be Cobb-Douglas in nature. Thus, the tax rate changes proposed by the reform cause the quantities demanded of the goods impacted by the tax changes to respond in such a way that the total tax-inclusive expenditures by consumers on each of these items remain constant. Furthermore, demand is not changed for the other goods and services whose tax rates and prices are not changed. Comparing the incidence of both tax systems indicates how the burden of the proposed tax system across expenditure groups compares with that of the pre-reform system.

\section{Distributive Impact Analysis of Existing Tax System}

The overall incidence of GST is obtained by multiplying the effective tax rates derived for each commodity by the total expenditures made on that item by all households in our sample. The overall incidence of the GST is estimated to be BZD 9,676,563, which is equivalent to $9.42 \%$ of total expenditures by the households in the sample.

To simplify the presentation, the 1500 expenditure items are then aggregated into ten commodity groups. The breakdown of this incidence by broad categories of commodities, shown in Table 2, reveals that the GST paid on expenditures on clothing and cosmetics constitutes $41.85 \%$ of GST revenue collections. The GST levied on expenditures on furni- 
ture and equipment and other goods and services constitute $16.82 \%$ and $14.98 \%$ of GST incidence, respectively.

Table 2. Estimate of the overall GST revenue before reform.

\begin{tabular}{ccccc}
\hline & Category of Expenditure & $\begin{array}{c}\text { Total Expenditure } \\
\text { (BZD) }\end{array}$ & $\begin{array}{c}\text { GST Revenue by } \\
\text { Category (BZD) }\end{array}$ & $\begin{array}{c}\text { Share of Total GST } \\
\text { Revenue (\%) }\end{array}$ \\
\hline & Food & $(1)$ & $(2)$ & $(3)$ \\
1 & Clothing and cosmetics & $18,514,610$ & 76,6384 & 7.92 \\
2 & Housing utilities & $32,509,220$ & 404,9642 & 41.85 \\
3 & Health & $6,171,923$ & 5.14 \\
4 & Furniture and house equipment & $13,831,400$ & 162,759 & 16.82 \\
5 & Transportation & $2,652,724$ & 90,960 & 7.94 \\
6 & Entertainment & $6,498,456$ & 694,777 & 2.80 \\
7 & Education & $3,613,316$ & 270,944 & 1.27 \\
8 & Hotels and restaurants & $2,353,328$ & 122,892 & 0.10 \\
9 & Other goods and services & 2448,619 & 9677 & 14.98 \\
10 & Grand total & $16,288,255$ & $1,449,549$ & 100.00 \\
\hline
\end{tabular}

To evaluate the distributional impacts of the GST, the households in the sample are sorted in ascending order based on the amount of their total expenditures. As shown in Table 3, they are divided equally into five groups, each representing $20 \%$ of the number of households in the sample. The summation of the GST collected on the sales of all the commodities within each quintile generates the total GST collected on the expenditures of the individuals in that quintile.

Table 3. Estimate of the GST revenue by quintile before reform.

\begin{tabular}{|c|c|c|c|c|c|c|c|}
\hline & Quintile & $\begin{array}{l}\text { Total } \\
\text { Expenditure } \\
\text { (BZD) }\end{array}$ & $\begin{array}{c}\text { Average } \\
\text { Household } \\
\text { Expenditure } \\
\text { (BZD) }\end{array}$ & $\begin{array}{l}\text { Total GST } \\
\text { Revenue } \\
\text { (BZD) }\end{array}$ & $\begin{array}{c}\text { GST Revenue Share } \\
\text { of Quintile } \\
\text { Expenditure } \\
(\%)\end{array}$ & $\begin{array}{c}\text { GST Share of } \\
\text { Total GST } \\
\text { Revenue } \\
(\%)\end{array}$ & $\begin{array}{c}\text { Average Tax } \\
\text { Payment by Each } \\
\text { Household } \\
\text { (BZD) }\end{array}$ \\
\hline & & (1) & (2) & (3) & (4) & (5) & (6) \\
\hline 1 & Quintile 1 & $2,587,941$ & 5675 & 170,537 & 6.59 & 1.76 & 374 \\
\hline 2 & Quintile 2 & $6,702,503$ & 14,698 & 529,330 & 7.90 & 5.47 & 1161 \\
\hline 3 & Quintile 3 & $11,603,869$ & 25,447 & $1,000,531$ & 8.62 & 10.34 & 2194 \\
\hline 4 & Q̄uintile 4 & $20,435,106$ & 44,814 & $1,852,196$ & 9.16 & 19.14 & 4062 \\
\hline 5 & Q̄uintile 5 & $61,352,433$ & 132,511 & $6,123,799$ & 9.98 & 63.28 & 13,226 \\
\hline 6 & Grand Total & $102,681,851$ & 44,629 & $9,676,363$ & 9.42 & 100.00 & 4,231 \\
\hline
\end{tabular}

With regard to the progressivity of the GST tax system, Table 3, column 4 reports that households in the lowest quintile pay $6.59 \%$ of their total expenditures as GST. However, the average GST tax burden rises to $7.90 \%$ for quintile $2,8.62 \%$ in quintile 3 , and $9.16 \%$ in quintile 4 , with households in quintile 5 paying $9.98 \%$ of their total expenditures as GST. This trend shows that the GST tax system is consistently progressive as the level of total household expenditures increases. It is clear that the nature of the GST in Belize and the policy measures taken since 2010 have made the GST a highly progressive indirect tax. The government's policy to increase the progressivity of the GST was successful. The following question remains to be answered: what was the fiscal cost (tax expenditure) of introducing progressivity in this manner into the GST?

The amounts of GST paid by households in each quintile as a percentage of total GST incidence are reported in Table 3, column 5. It can be observed that households in the first quintile pay only $1.76 \%$ of the total GST collections. In each subsequent quintile, the share of total GST collected increases to $5.47 \%$ for households in quintile 2 and then to $10.34 \%, 19.14 \%$, and $62.28 \%$ for households in quintile 3, 4, and 5, respectively. Expressed differently, in column 6, it is reported that the average contribution to GST revenues by households in quintile 1 is BZD 374. This amount increases to BZD 1161, BZD 2194, BZD 4062, and BZD 13,226, for quintiles 2, 3, 4, and 5, respectively. This indicates the importance 
of designing tax policies that accurately target tax relief on purchases of specific goods or services purchased predominately by the poor. If such relief spills over to the purchases made by higher income individuals, the potential revenue loss can be huge.

\section{Estimates of the Overall Incidence of Proposed Tax Systems}

The tax treatment of all commodities under GST requires them to be classified as taxable, zero rated, or exempted. The proposed reforms changed the components within each of these tax groupings. The first set of changes contains all commodities that have been zero rated but exempted after adjustment for reform from the GST. The second group constitutes the zero-rated items that after adjustment are entirely subject to GST. The final group contains the commodities that are moved from the exempt category to become fully taxable. The proposed reforms involve the elimination of the zero-rate tax except for sales of items exported. Exemption from GST taxation is allowed for only 86 items (including unprocessed food, education-related costs, financial services, and medical services).

Figures 1 and 2 break down the amount of sales of goods and services that are either exempt from the VAT or zero rating as discussed above. Figure 1 illustrates the proportions of expenditures given tax preferences by type of expenditure, and Figure 2 breaks down the amount in terms of tax-preferred spending by quintile. The main message from these data is that almost $80 \%$ of all exempt expenditures are made for food, followed by health $(8 \%)$ and entertainment $(7 \%)$. From Figure 2, we can observe that of the total tax-preferred expenditures, $54 \%$ are purchased by the highest income group, quintile 5 . In contrast, for the lowest income group, quintile 1 , the proportion of total tax-preferred expenditures is only $6 \%$ of the total.

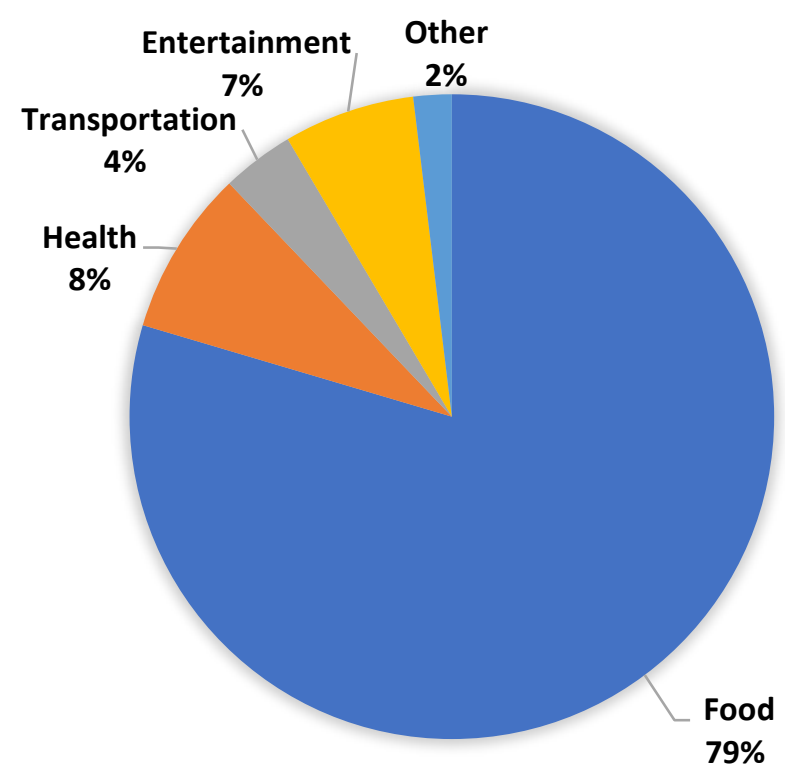

Figure 1. Distribution of expenditures on exempt or zero-rated sales by type.

Table 4 shows the estimate of the overall GST revenue after reform. To measure the impact of the proposed reforms, the input shares need to be estimated for all items that have previously been zero rated and are now given a tax exemption. The importance of this adjustment arises because sellers of zero-rated items can claim a refund for the tax paid on inputs of their final product. If these zero-rated items become exempt because of the proposed reform, the sellers would no longer be allowed to submit refund claims for the taxes paid on inputs. 


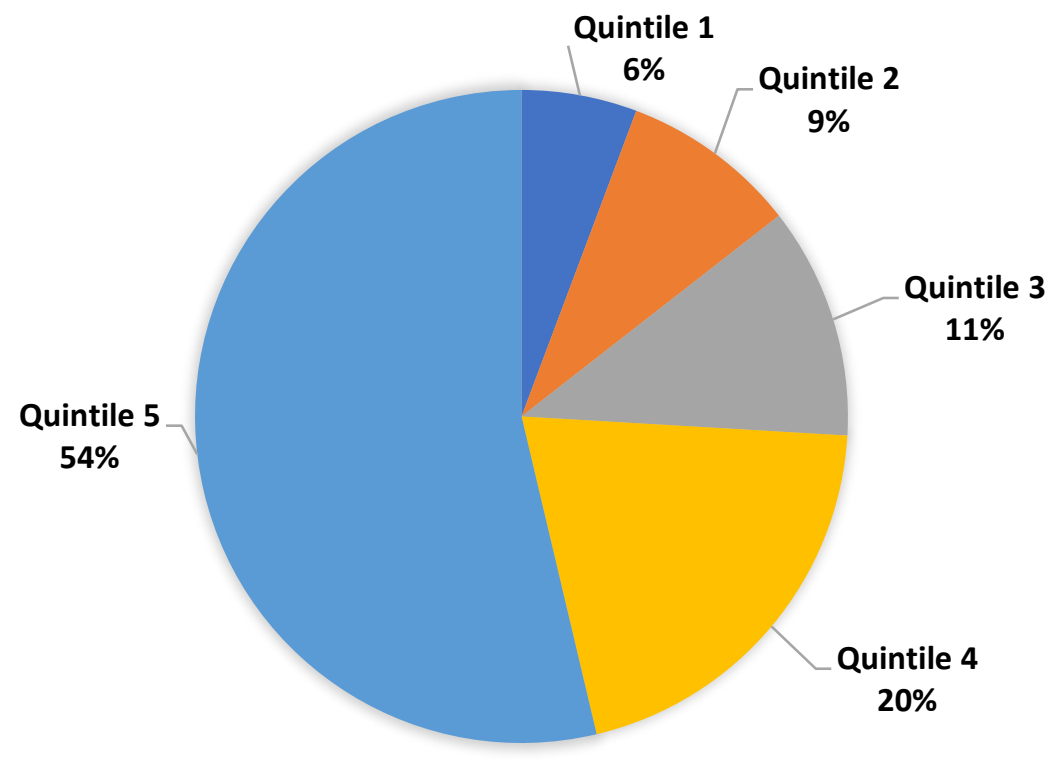

Figure 2. Expenditures by quintile on exempt or zero-rated sales.

Table 4. Estimate of the overall GST revenue after reform.

\begin{tabular}{cccc}
\hline & Category of Expenditure & GST Revenue by Category (BZD) & GST Share of Total GST Revenue (\%) \\
\hline & & $(1)$ & $(2)$ \\
1 & Food & $1,731,011$ & 15.27 \\
2 & Clothing and cosmetics & $4,066,147$ & 35.87 \\
3 & Housing utilities & 771,964 & 6.81 \\
4 & Furniture and house equipment & $1,729,986$ & 15.26 \\
5 & Health & 154,305 & 1.36 \\
6 & Transportation & 780,076 & 6.88 \\
7 & Entertainment & 330,965 & 2.92 \\
8 & Education & 141,018 & 1.24 \\
9 & Hotels and restaurants & 9259 & 0.08 \\
10 & Other goods and services & $1,622,480$ & 14.31 \\
11 & Grand total & $11,337,210$ & 100.00
\end{tabular}

The category that yields the highest revenue is clothing and cosmetics, with $35.87 \%$ of total GST collections. In contrast to the current tax system, the GST from food taxation is now second in importance, at $15.27 \%$ of total GST revenues. This represents an almost doubling of its contribution from $7.92 \%$ under the current system. The other two sectors that contribute the most to the GST revenue collections are furniture and household equipment $(15.26 \%)$ and other goods and services (14.31\%). The tax reform measures would shift the relative burden of the GST toward food items.

\section{Distributive Impact Analysis of Proposed Tax System}

To evaluate the distributional impacts across different quintiles, the household sample is again ranked into the same five groups by total household expenditures. After calculating the GST revenue on each commodity, the GST revenues of all commodities within each expenditure quintile are estimated.

The findings (Table 5, column 2) confirm that the overall burden of the GST after the reform remains progressive. The effective tax rate rises consistently from the lowest to the highest expenditure quintile. However, when comparing the effective tax rates by quintile pre-reform (Table 3, column 4), the effective rates after the reform are decidedly less progressive. Post-reform, households in the lowest quintile would pay $9.45 \%$ of their total expenditures as GST compared with $6.59 \%$ under the existing tax system. In comparison, households in the highest quintile would pay $11.45 \%$ of their total expenditures as GST 
rather than $9.98 \%$ under the current tax system. The ratio of the effective tax rate in quintile 5 to the effective tax rate in quintile 1 is 1.51 pre-reform, decreasing to 1.21 post-reform. Even with this extreme base-broadening tax policy with a single statutory tax rate, the GST still has a progressive tax incidence. This is consistent with the findings of [12] and [13], who found that even when a single statutory rate of tax is applied to all goods and services that can be administratively taxed, the VAT in less developed countries is an overall progressive tax.

Table 5. Estimate of the GST revenue by quintile after reform.

\begin{tabular}{cccccc}
\hline & Quintile & $\begin{array}{c}\text { Total GST } \\
\text { revenue (BZD) }\end{array}$ & $\begin{array}{c}\text { GST Revenue Share } \\
\text { of Quintile } \\
\text { Expenditure (\%) }\end{array}$ & $\begin{array}{c}\text { GST Share of Total GST } \\
\text { Revenue (\%) }\end{array}$ & $\begin{array}{c}\text { Average Tax Payment by } \\
\text { Each Household (BZD) }\end{array}$ \\
\cline { 2 - 6 } & & $\mathbf{( 1 )}$ & $\mathbf{( 2 )}$ & $\mathbf{( 3 )}$ & $\mathbf{( 4 )}$ \\
\hline 1 & Quintile 1 & 244,514 & 9.45 & 2.16 & 536 \\
2 & Quintile 2 & 664,036 & 9.91 & 5.87 & 1456 \\
3 & Quintile 3 & $1,203,924$ & 10.37 & 10.62 & 2640 \\
4 & Quintile 4 & $2,202,856$ & 10.77 & 61.93 & 4830 \\
5 & Quintile 5 & $7,021,880$ & 11.45 & 100.00 & 15,188 \\
6 & Grand total & $11,337,210$ & 11.04 & 4957 \\
\hline
\end{tabular}

From Table 5, column 1, it can be seen that GST revenues increased in absolute amounts for each quintile compared with pre-reform values. However, there was a shift in the relative burden of the taxes collected between quintiles. Under the reformed tax system, tax paid by households in quintile 1 increased from the previous level of $1.76 \%$ of total GST collections to $2.16 \%$ of total GST revenues (Table 5, column 3). In contrast, the total GST paid by households in the highest quintile decreased from $63.28 \%$ of total GST to $61.93 \%$ of total GST collections. In terms of the overall burden post-reform, quintile 5 households pay over 28 times more GST tax than households in quintile 1 . However, pre-reform, the households in the highest quintile paid 35 times more GST than households in the lowest quintile.

These results are consistent with the findings of others [14,32-34], who suggested that a broadening of the VAT base has a proportionally greater negative impact on the well-being of lower income groups than on those who are better off. The question now to be addressed is whether the current progressive tax policies are a cost-effective way of assisting the poorer residents of Belize.

\section{Tax Expenditures versus Direct Expenditure Programs for Poverty Alleviation}

According to Table 5, column 1, the increased burden of GST imposed by the proposed reform relative to the total expenditures of the quintile falls more heavily on the households in the lower expenditure quintiles. This is shown by the downward trend of incremental GST revenue as a percentage of expenditures, starting from $2.86 \%$ for quintile 1 and shrinking to $1.47 \%$ for quintile 5 . However, in terms of absolute values of the tax expenditures arising from the existing preferential tax treatment of certain commodities (Table 5, column 2), the incremental increase in the average tax payment by each household rises by BZD 162 per household in the first quintile to BZD 1962 per household in the fifth quintile.

The current tax policies designed to reduce the tax burden of GST on the poor were primarily crafted to remove the tax content of GST from food purchases. However, in Belize, the households in quintile 5 purchase more than $55 \%$ of the total amount of food sold in the country. On a per-household basis, those in quintile 5 have food expenditures that are nine times greater than those in quintile 1. Consequently, while tax policies lower the effective tax rate on food assistance, the poor households in quintile 1 received over 12 times the amount of benefits when compared with those received by households in quintile 5 (Table 6, column 2). From column 3, it can be observed that the households in 
the top two expenditure quintiles benefited from over $75 \%$ of the tax relief from these tax expenditures. In comparison, the bottom two quintiles received about $12.5 \%$ of the total tax cost of these policies. The bottom quintile, where the very poor are located, received only $4.45 \%$ of the benefits.

Table 6. Incremental GST revenue and payment by each household from reform.

\begin{tabular}{ccccc}
\hline Quintile & $\begin{array}{c}\text { Incremental GST Revenue as } \\
\text { a Share of Total Quintile } \\
\text { Expenditure * (\%) }\end{array}$ & $\begin{array}{c}\text { Incremental Average Tax } \\
\text { Payment by Each Household } \\
\text { (BZD) ** }\end{array}$ & $\begin{array}{c}\text { Proportion of Incremental } \\
\text { Revenue Paid by Quintile (\%) }\end{array}$ \\
\hline & & $(1)$ & $(2)$ & $(3)$ \\
2 & Quintile 1 & 2.86 & 162 & 4.45 \\
3 & Quintile 2 & 2.01 & 295 & 8.11 \\
4 & Quintile 3 & 1.75 & 446 & 12.24 \\
5 & Quintile 4 & 1.61 & 768 & 21.12 \\
6 & Average & 1.47 & 7962 & 54.08 \\
\hline
\end{tabular}

* (Table 5 column 4) minus (Table 3 column 6). ${ }^{* *}$ (Table 5 column 2) minus (Table 3 column 4).

Comparing the total GST revenues from our sample of households before the tax reform of BZD 9,676,563 (Table 2 column 2) with the revenues after the reform of BZD $11,337,210$ (Table 4, column 1), the increase is equal to $17 \%$ of the revenues before the reform. In 2018, the GST revenues were BZD 320,031,000 [25]. Thus, a 17\% increase in revenues would add BZD 54,405,270 annually to the available revenue of the government. Hence, the current tax preferences are annually creating tax expenditures of this amount. Supposing that these tax expenditures were viewed as budgetary expenditures to be used to alleviate the poverty impact of GST, it must be concluded that they are an extraordinarily inefficient policy instrument.

\section{The Option of Targeted Cash Transfers}

To mitigate the increased burden of GST on lower income households, targeted cash transfers have been proposed. In principle, the negative distributional effects of a higher or broader GST/VAT system can be mitigated through government expenditures that directly target poor households. Using general equilibrium analysis, it has been argued that in developing countries, targeted cash-transfer policies are much more effective than tax exemptions on food items in reducing poverty and the income inequality gap [35].

Applying a welfare function for individuals, Keen showed that even a poorly designed targeted transfer program would mitigate the adverse effects of imposing VAT on food items [15]. There exist many instruments that governments can use to address distributional concerns. The question of how well public spending can be targeted to mitigate the effects of removing the reduced VAT rates and at what cost remains to be answered [9].

While targeted cash transfers, such as income-related transfers in the UK or refundable tax credits in Canada, may effectively achieve distributional targets in many advanced countries, such instruments may not be administratively possible in developing countries. The fundamental problem is that the income tax or social security systems in developing countries have little or no contact with those living below the poverty line. Consequently, there is no efficient institutional mechanism in place to systematically deliver monetary benefits. Instead, the public provision of goods and services seems to be a more promising strategy [15]. Reference [14] found that spending a portion of the funds raised from a uniform rate VAT on education and health would benefit $40 \%$ of the poorest households in Ethiopia.

A study evaluated four cash transfer schemes involving different identification procedures to target the poorest households in the Philippines and compensate them for the burden of removed reduced tax rates on fuels [17]. Their findings show that although all four alternative transfer schemes are more progressive, the actual effectiveness of this 
policy depends on the amount of administrative costs and the method of identifying the target groups.

One of the forms of targeted transfer program designed to assist the poor is the Food Pantry Program in Belize. It has been shown that such programs can be very cost effective, even if targeting the beneficiaries is not perfect or the administrative costs are relatively high [36]. This is because the foods for the program procured from local food banks cost much less than similar products from supermarkets. In addition, as the beneficiaries of such programs are likely to belong to low-income groups, they tend to use most of the food received.

In Belize, the Food Pantry Program was introduced in 2012 to compensate for 50\% of weekly household food baskets at the value of BZD 25 (USD 12.50) each. Each eligible household receives BZD 1300 annually under this program. The program currently covers 3400 households or approximately 17,000 people, representing about $4.4 \%$ of the entire population of Belize [37].

Although there is no publicly available data on the cost of targeting the existing Food Pantry Program in Belize (including administrative, identification, and transfer costs), in practice, the extension of the scale of the program would increase these costs. However, a review of similar programs provides estimates of the costs that need to be considered.

The cost of targeting programs has a positive correlation with the success rates of the programs implemented. For instance, calculations by [38] and [39] showed that the administrative costs of the less efficient targeting models, such as geographic targeting, range from $6 \%$ to $7 \%$ of programmed costs. In contrast, according to [38], the average cost of administrating individual targeting schemes with the best success rates in terms of targeting can be as high as $29 \%$ of total programmed costs.

It has been estimated that the administrative costs of targeting and universal programs in low-income countries are about 30\% and 15\%, respectively [40]. From a survey of programs [41], the total administrative costs for selected targeted programs in Latin America are between the estimates of $26 \%$ by [38] and $30 \%$ by [40].

If the targeting and other administrative costs in Belize did not exceed $30 \%$ of the amount the beneficiaries receive, the per-household cost of the Food Pantry Program would be BZD 1690 per year. If the additional GST revenue (BZD 54,405,270) were allocated to extend the Food Pantry Program, this would cover about 32,200 additional households or 161,000 people.

Although Belize is an upper-middle-income country based on per-capita income, at USD 4906 per capita in 2017 [22], it has a high incidence of poverty. It was reported by [23] that approximately $41.3 \%$ of the population live in poverty, with $16 \%$ facing extreme poverty. With a population in 2018 of 383,071 , the estimated number of individuals in poverty is 158,208 , with a subgroup of 61,291 individuals in extreme poverty.

With an average of 5.0 individuals per household, these population numbers translate into 31,645 and 12,268 households, respectively. Hence, the additional revenues from the reform of the GST would be more than enough to finance the costs of broadening the Food Pantry Program to cover all the 31,645 households that are considered to be in poverty. Alternatively, the system might be broadened in a more limited way with a supplemental allowance provided to families in extreme poverty. These estimates are made assuming that the administrative costs would be $30 \%$ of the food subsidies. The evidence to date indicates that with such a broad-based program, the administrative costs might be considerably less than this amount [39]. As shown in Figure 3, before the reform, 4.4\% of households were covered by the food basket program, which left $11.6 \%$ of the extremely poor population not being covered by this program.

The Food Pantry Program grant of BZD 1300 a year is far above the average of BZD 223 GST paid on all food purchases or BZD 536 of GST paid on all purchases of the quintile 1 households. This targeted program would be able to finance meaningful support to all $41.3 \%$ of the families in Belize that are classified as living in poverty. From Figure 4, we can see that the additional funds would allow an increase in coverage of the food program 
by an amount equal to $40 \%$ of the total households, bringing the total coverage to $44.4 \%$ of all the households in Belize. The combined reformed GST system and the enhanced Food Pantry Program create a much more progressive tax and expenditure system than the pre-reform tax preferences for pro-poor consumption.

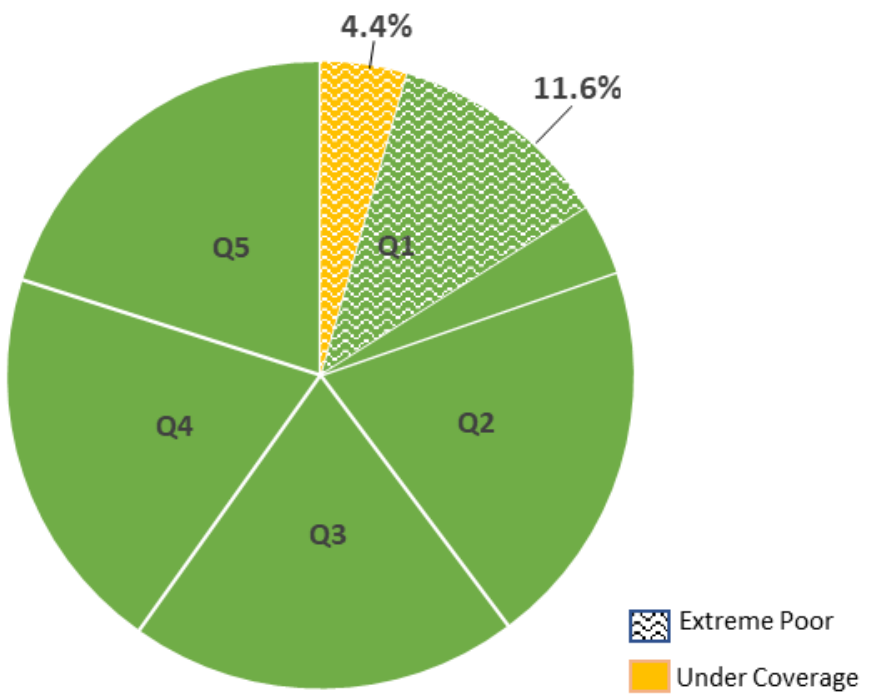

Figure 3. Before reform coverage of Food Pantry Program.

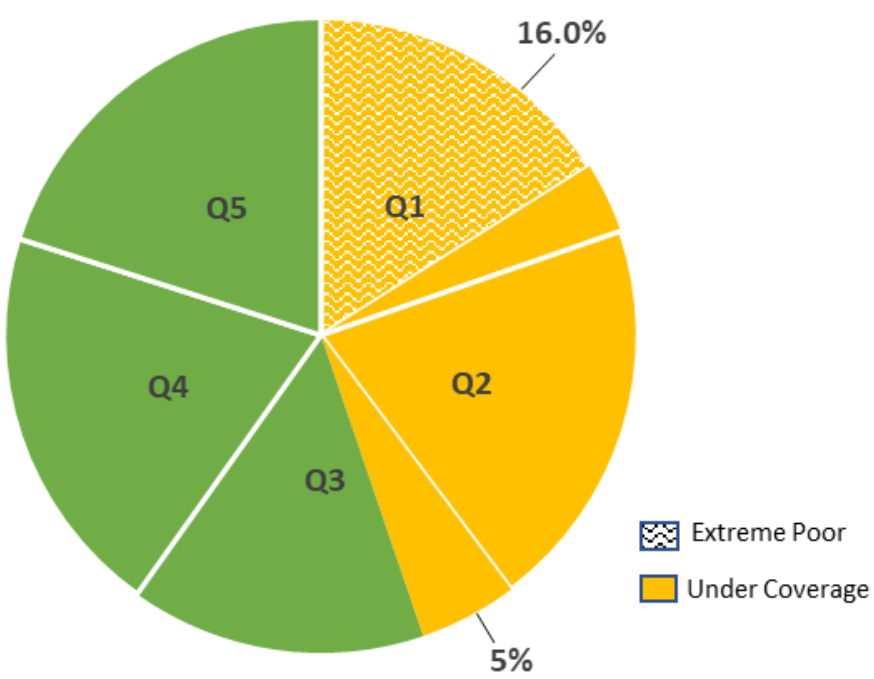

Figure 4. After reform proposed coverage of Food Pantry Program.

The quantitative results of this paper provide strong evidence to support the findings of [15] and [35] that suggest that reducing GST rates is a highly inefficient way of assisting the poorer households in society. Keen further emphasized that "even poorly targeted spending may be a better way to support the poor than a reduced rate".

The findings of this paper clearly show how a GST system intended to give relief to the poor through exemptions and zero rating could be reformed into one that is a broad-based, single-rate system. The resulting system would generate more revenue for the government while still maintaining a progressive incidence. The additional revenues could be utilized to finance a targeted transfer program that would deliver substantial food expenditure support to poor households and narrow the country's income inequality gaps.

\section{Conclusions and Policy Recommendations}

All of the major tax systems implemented by governments must be seen as fair if they are to remain stable and sustainable in the long run. If a tax is viewed as unfair, then there 
will be constant demand to make adjustments to the system to address the demands of special interest groups. The problems associated with the administration of and compliance with a VAT system grow exponentially with the number of goods and services that receive tax preferences. In a single-stage sales tax system, a good is exempted from taxation, and only that good and its sales are affected in terms of special record keeping and additional compliance costs. However, with VAT, all sellers of such an item and the buyers who use it as an input in production must keep a special record of these sales and purchases separately. This is especially burdensome for small businesses that do not have sophisticated computer systems to track these special transactions. Even in the European Union today, small and medium enterprises account for more than $90 \%$ of the entire compliance costs associated with the VAT operation [42].

While in many countries, VAT has been the major tax instrument for raising revenue for their governments, it has in some cases collapsed. The experiences of Malaysia and previously of Ghana and Belize are examples. Usually, the collapse comes as a result of political concerns of tax fairness and compliance issues. In other countries, particularly in Latin America, it has occasionally been severely weakened by the proliferation of tax preferences and only salvaged by implementing major tax reforms [20]. Belize is a good case study of a situation where the collapse of the GST system seems imminent unless a major reform is undertaken. Over $40 \%$ of the entire workforce in GST tax administration are assigned to auditing and processing claims for refunds. Furthermore, the backlog of unprocessed claims in 2016 was equal in value to $50 \%$ of the annual revenues of the GST system. This is an institutionally unsustainable situation.

This empirical study shows that the objective of raising a substantial amount of revenue with a single-rate, broad-based GST system in Belize is not in conflict with the government's income distribution objectives. Our analysis shows that currently, the GST is highly progressive in Belize, with the effective tax rate paid by households in the top quintile 1.5 times the effective tax rate paid by those in the bottom quintile. However, the current tax system has required an extensive array of tax exemptions and zero rating of items, causing it to become impossible to efficiently administer. Even after eliminating the zero rating of all goods sold domestically and a drastic reduction in the number of GST-exempt goods, the tax system remains progressive. The average tax rate of households in the top quintile is approximately 1.2 times that of those in the bottom quintile.

Fortunately, in Belize, a small but well-run food pantry program covers just $4.4 \%$ of the population that could be beneficially expanded. Even if the administration costs of the program rose to $30 \%$ of the cost of the expansion of the program, the additional revenue generated through the new GST system would allow the government to expand its Food Pantry Program to cover all households in the bottom $40 \%$ of the income distribution by expanding the program from 17,000 to 161,000 individuals. This would make the overall tax and expenditure system much more progressive in its incidence than the existing system of tax preferences for food and other items. Such an improvement in the fairness of the overall fiscal system would enhance its political sustainability.

In addition to improving the tax structure and revenue enhancement, these reforms would eliminate the waste of resources incurred in administering the current set of tax preferences. The saving of these resources would amount to at least $40 \%$ of the personnel cost of the current GST system. The reallocation of these highly skilled administrators in the tax system would enhance the effectiveness of the revenue system and improve taxpayer service.

To improve the effectiveness of the additional GST revenues from this reform in combating poverty, the government might wish to think of a menu of expenditure programs targeted to various needy groups rather than simply focusing on the food needs of the poor. Particularly, as the food needs of a larger group of the poorest households are met, it would be wise to examine other critical needs of particular groups. The outcome of this process is what has been referred to as a personalized VAT [18]. In such a case, part of the revenues would be allocated to satisfying the targeted needs of different poverty groups 
that might have very different critical needs. In Belize, the designers of tax policies must be aware of this need to politically link the effectiveness of a broad-based, single-rate GST as a revenue raiser to use some of the funds to address poverty in the country. This is a critical element in maintaining a sustainable GST in Belize.

Author Contributions: Conceptualization, G.P.J.; methodology, G.P.J. and C.-Y.K.; software, Z.A. and M.S.; validation, G.P.J., Z.A. and M.S.; investigation, Z.A. and G.P.J.; writing-original draft preparation, Z.A. and G.P.J.; writing - review and editing, G.P.J., Z.A. and M.S.; supervision, G.P.J. and C.-Y.K. All authors have read and agreed to the published version of the manuscript.

Funding: This research received no external funding.

Institutional Review Board Statement: Not applicable.

Informed Consent Statement: Not applicable.

Data Availability Statement: Not applicable.

Acknowledgments: The assistance, comments, and suggestions of Alberto Barreix, Andrew Balcom, Hasan Ulas Altiok, Majid Hashemi, Geraldine Young, Joseph Waight, and many other civil servants who assisted during the preparation of this study are greatly appreciated. Any errors that remain are the responsibility of the authors.

Conflicts of Interest: The authors declare no conflict of interest.

\section{References}

1. Adhikari, B. Does Introducing a VAT Increase Efficiency? Evidence from Synthetic Control Methods; Tulane University: New Orleans, LA, USA, 2014.

2. Ebeke, C.; Mansour, M.; Gregoire, R.G. VATs, LTUs, and SARAs: The Power to Tax in Africa; IMF Working Paper; International Monetary Fund: Washington, DC, USA, 2015.

3. Keen, M.; Lockwood, B. The value added tax: Its causes and consequences. J. Dev. Econ. 2010, 92, 138-151. [CrossRef]

4. Ufler, A. Quasi-Experimental Analysis on the Effects of Adoption of a Value Added Tax. Econo. Inq. 2014, 52, 1364-1379.

5. Chari, V.V.; Kehoe, P.J. Optimal fiscal and monetary policy. In Handbook of Macroeconomics; Taylor, J.B., Woodford, M., Eds.; North Holland Publishing Co.: Amsterdam, The Netherlands, 1999; Volume 1, Part C; pp. 1671-1745.

6. Ahmad, E.; Stern, N. Alternative Sources of Government Revenue: Illustrations from India, 1979-80. In The Theory of Taxation for Developing Countries; Published for the World Bank by Oxford University Press; Newbery, D., Stern, N., Eds.; Oxford University Press: New York, NY, USA, 1987.

7. Carlson, G.N.; Patrick, M.K. Addressing the Regressivity of a Value-Added Tax. Natl. Tax J. 1989, 42, 339-351. [CrossRef]

8. Politi, R.B.; Mattos, E. Ad-valorem tax incidence and after-tax price adjustments: Evidence from Brazilian basic basket food. Can. J. Econ. 2011, 44, 1438-1470. [CrossRef]

9. Van Oordt, M. Zero-Rating versus Cash Transfers under the VAT. Fiscal Stud. 2018, 39, 489-515. [CrossRef]

10. Bird, R.M.; Gendron, P. The VAT in Developing and Transitional Countries; Cambridge University Press: Cambridge, UK, 2007.

11. Lyssiotou, P.; Savva, E. Who pays taxes on basic foodstuffs? Evidence from broadening the VAT base. Int. Tax Public Financ. 2020, 27, 1-36. [CrossRef]

12. Bachas, P.; Gadenne, L.; Jensen, A. Informality, Consumption Taxes and Redistribution; Policy Research Working Paper 9267; Development Research Group; World Bank Group: Washington, DC, USA, 2020.

13. Jenkins, G.P.; Jenkins, H.; Kuo, C.-Y. Is the Value Added Tax Naturally Progressive (Working Paper 1059); Economics Department, Queen's University: Kingston, ON, Canada, 2006.

14. Muñoz, S.; Cho, S. Social Impact of a Tax Reform: The Case of Ethiopia. In Helping Countries Develop: The Role of Fiscal Policy; Sanjeev, G., Clements, B., Inchauste, G., Eds.; International Monetary Fund: Washington, DC, USA, 2004; pp. $353-384$.

15. Keen, M. Targeting, Cascading, and Indirect Tax Design. Indian Growth Dev. Rev. 2014, 17, 181-201. [CrossRef]

16. Alastair, T. The Distributional Effects of Consumption Taxes in New Zealand (Working Papers in Public Finance; Working Paper 08; Victoria University of Wellington: Wellington, New Zealand, 2015. Available online: http:/ / researcharchive.vuw.ac.nz/xmlui/ bitstream/handle/10063/4668/working\%20paper.pdf?sequence=1 (accessed on 20 June 2020).

17. Newhouse, D.L.; Zakharova, D. Distributional Implications of the VAT Reform in the Philippines. IMF Working Papers. 2007. Available online: https:/ / ssrn.com/abstract=1007902 (accessed on 20 June 2020).

18. Barreix, A.; Bès, M.; Roca, J. Personalized VAT: Increasing Revenue Collection and Compensating the Poor; Inter-American Development Bank: Washington, DC, USA, 2010.

19. Barreix, A.; Bès, M.; Roca, J. Solving the Impossible Trinity of Consumption Taxes: Personalized VAT: Increasing Revenue Collection and Compensating the Poor; Inter-American Development Bank: Washington, DC, USA, 2012. 
20. Bernardi, L.; Alberto Barreix, A.; Marenzi, A.; Profeta, P. Tax Systems and Tax Reforms in Latin America; Routledge Studies in the Modern World Economy; Routledge: Abingdon, UK, 2013.

21. Jenkins, G.P.; Kuo, C.Y. Fiscal Adjustment for Sustainable Growth in Belize; Inter-American Development Bank, Regional Operations Department II: Washington, DC, USA, 2006.

22. World Bank. Development Indicators. 2018. Available online: http:/ / databank.worldbank.org (accessed on 15 July 2019 ).

23. Borgen Project. Path to Improvement: Top 10 Facts about Poverty in Belize. 2018. Available online: https://borgenproject.org/ path-to-improvement-top-10-facts-about-poverty-in-belize/ (accessed on 20 June 2020).

24. Central Bank of Belize. Annual Report; Central Bank of Belize: Belize City, Belize, 2018.

25. OECD. Revenue Statistics Latin America, Details of Revenue: Belize, Value Added Tax Revenues. 2018. Available online: https:/ / stats.oecd.org/Index.aspx?DataSetCode=REVBLZ (accessed on 8 August 2020).

26. Godbout, L.; St-Cerny, S. Are consumption taxes regressive in Quebec? Can. Tax J. 2011, 59, 463-493.

27. Cnossen, S. Introducing a Modern GST in India: Need for Further Debate. Tax Notes Int. 2012, 66, 1267-1283.

28. Jenkins, G.P.; Kuo, C.-Y. A VAT Revenue Simulation Model for Tax Reform in Developing Countries. World Dev. 2000, 28 , 763-774. [CrossRef]

29. Cubero, R.; Hollar, I.V. Equity and Fiscal Policy: The Income Distribution Effects of Taxation and Social Spending in Central America; IMF Working Paper No 10/112; International Monetary Fund: Washington, DC, USA, 2010.

30. Caspersen, E.; Metcalf, G. Is a Value Added Tax Regressive? Annual Versus Lifetime Incidence Measures. Natl. Tax J. 1994, 47, 731-746. [CrossRef]

31. Slintáková, B.; Klazar, S. Impact of Harmonisation on Distribution of VAT in the Czech Republic. Prague Econ. Pap. 2010, 19, 133-149. [CrossRef]

32. Carbonnier, C. Who Pays Sales Taxes? Evidence from French VAT reforms, 1987-1999. J. Public Econ. 2007, 91, 1219-1229. [CrossRef]

33. Atkinson, T. The "Mirrlees Review" of UK Taxation. Royal Economic Society. Newsletter 2013, 160, 5-6.

34. Gaarder, I. Incidence and Distributional Effects of Value Added Taxes. Econ. J. 2019, 129, 853-876. [CrossRef]

35. Alva, A.P.; Tavares, M.M.; Tam, X. The Distributional Implications of Fiscal Consolidation in Developing Countries; International Monetary Fund: Washington, DC, USA, 2016.

36. Wodon, D.; Wodon, N.; Wodon, Q. How Cost Effective Are Food Pantry Programs for the Poor Likely to Be? (Nonprofit Research Project, MPRA No. 56945). Munich Personal RePEc Archive. 2013. Available online: https://mpra.ub.uni-muenchen.de/56945/ (accessed on 23 July 2020).

37. Food and Nutrition Security Platform. Food Pantry Program. 2020. Available online: https://plataformacelac.org/en/programa/ 325 (accessed on 15 June 2020).

38. Grosh, M.E. Administering Targeted Social Programs in Latin America: From Platitudes to Practice; World Bank: Washington, DC, USA, 1994.

39. Gwatkin, D.R. The Current State of Knowledge about Targeting Health Programs to Reach the Poor; World Bank: Washington, DC, USA, 2000.

40. Smith, J.; Subbarao, K. What Role for Safety Net Transfers in Very Low Income Countries; Social Protection Discussion Paper, No.30; World Bank Institute: Washington, DC, USA, 2003.

41. Dutrey, A.P. Successful Targeting? Reporting Efficiency and Costs in Targeted Poverty Alleviation Programmes; Social Policy and Development Programme Paper No. 35; United Nations Research Institute for Social Development: Geneva, Switzerland, 2007.

42. KPMG. Study on Tax Compliance Costs for SMEs; European Commission: Brussels, Belgium, 2018. Available online: https: / / op.europa.eu/en/publication-detail/- / publication/0ed32649-fe8e-11e8-a96d-01aa75ed71a1 (accessed on 30 March 2019). 